\title{
Structure Studies of the Prepared Novel Hydrazone Schiff's Base Complexes Using Spectroscopic, Thermal Analyses and Their Biological Activities
}

\author{
M. A. Zayed, ${ }^{1}$ Arafa Belal, ${ }^{2}$ and S. M. A. H. Ragha ${ }^{2}$ \\ ${ }^{1}$ Chemistry Department, Faculty of Science, Cairo University, Giza 12613, Egypt \\ ${ }^{2}$ Chemistry Department, Faculty of Science, Port Said University, Port Said 42526, Egypt \\ Address correspondence to M. A. Zayed, mazayed429@yahoo.com
}

Received 29 September 2017; Revised 29 October 2017; Accepted 3 November 2017

Copyright (C) 2018 M. A. Zayed et al. This is an open access article distributed under the terms of the Creative Commons Attribution License, which permits unrestricted use, distribution, and reproduction in any medium, provided the original work is properly cited.

\begin{abstract}
The complexing behavior of benzoylhydrazone Schiff's base (A1), with the IUPAC name (2(1-hydrazonoethyl)phenol), towards the transition metal ions, namely, $\mathrm{Mn}(\mathrm{II}), \mathrm{Fe}(\mathrm{III}), \mathrm{Co}(\mathrm{II})$, $\mathrm{Ni}(\mathrm{II}), \mathrm{Cu}(\mathrm{II}), \mathrm{Zn}(\mathrm{II}), \mathrm{Hg}(\mathrm{II}), \mathrm{Ce}(\mathrm{IV})$, and $\mathrm{UO}_{2}(\mathrm{II})$, has been examined by elemental analyses, magnetic measurements of some of them, electronic spectra, FT-IR, ${ }^{1} \mathrm{H}-\mathrm{NMR}$, and ${ }^{13} \mathrm{C}-\mathrm{NMR}$. Thermal properties and decomposition kinetics of all complexes are investigated. The interpretation of kinetic parameters of thermal decomposition stages of some of them has been evaluated using CoatsRedfern equation. The antifungal activities of the free ligand and its metal complexes have been tested in vitro against two types of fungi: Aspergillus fumigatus, RCMB 02568; Candida albicans, RCMB 05036. Besides, two gram-positive (Bacillus subtilis, RCMB 010067; Streptococcus pneumoniae, RCMB 010010) and two gram-negative (Escherichia coli, RCMB 010052; Pseudomonas aeruginosa, RCMB 010043) bacteria were used as test organisms in order to assess the complexes' antimicrobial potential. It is clear from this survey that the A1 complexes are of high biological activities as antifungal, in which $\mathrm{Cu}-\mathrm{A} 1$ and $\mathrm{Co}-\mathrm{A} 1$ are the most efficient complexes in a level more or less approaches that of the amphotericin standard. It also indicates that the $\mathrm{Cu}-\mathrm{A} 1$ and $\mathrm{Mn}-\mathrm{A} 1$ have the largest biological effects on gram-positive bacteria of both kinds, and that $\mathrm{Cu}-\mathrm{A} 1$ complex has a more effect $(32.4 \pm 0.30)$ or of the same order of magnitude $(23.8 \pm 0.20)$ as that of the ampicillin standard (23.8 \pm 0.2$)$.
\end{abstract}

Keywords hydrazone Schiff's base; spectral studies; transition metal complexes; thermal analyses; biological activity

\section{Introduction}

Schiff's bases have been of good importance in coordination [1] and macrocyclic chemistry [2]. The synthesis of macrocyclic complexes have great potential applications in fundamental and applied sciences $[3,4,5]$; biochemistry, material science, catalysis, encapsulation, activation, transport and separation phenomena, hydrometallurgy, etc. and importance in the area of inorganic chemistry [6, 7]. The development of the work of bioinorganic chemistry has been another important factor in spurring the growth in interest in macrocyclic compounds [8]. The Schiff-base ligands with oxygen and nitrogen donor atoms in their structures act as good chelating agents for the transition and nontransition metal ions [9]. Coordination compounds with metal ions, such as copper, nickel, and iron, often enhance their activities [3]. There is a continuing interest in metal complexes of Schiff's bases because of the presence of both hard nitrogen or oxygen donor atoms in the backbones of these ligands. They readily coordinate with a wide range of transition metal ions yielding stable metal complexes, some of which have been shown to exhibit interesting physical and chemical properties [5] and potentially useful biological activities [6].

Schiff's bases [6] are still regarded as one of the most potential group of chelators for facile preparations of metallo-organic hybrid materials. In the past two decades, the properties of Schiff-base metal complexes stimulated much interest for their noteworthy contributions. These contributions are such as material science [10], catalysis of many reactions like carboxylation, hydroformulation, oxidation, reduction and epoxidation [11], their industrial applications [12], and their ability towards some toxic metals [13]. The Schiff-base compounds are considered highly interesting analytical reagents, because they enable simple and inexpensive determinations of different organic and inorganic substances [14]. The most important step in the development of metal complexes was perhaps the preparation of a new ligand, which exhibits unique properties and novel reactivity. Thus, the electron donor and electron acceptor properties of the ligand, structural functional groups, and the position of the ligand in the coordination sphere together with the reactivity of coordination compounds may be a factor of different studies [15, $16,17,18,19,20,21,22,23,24,25,26,27]$. Schiff's bases are compounds containing an azomethine group $(-\mathrm{CH}=\mathrm{N}-$ ) 
which have drawn attention for many years ago. Their metal complexes have been studied, with a variety of transition metal ions, since they frequently exhibit unusual structural properties [21].

Aspartic proteases are a class of enzymes that play a causative role in numerous diseases such as malaria (plasma epsins), Alzheimer's disease ( $\beta$-secretase), fungal infections (secreted aspartic proteases), and hypertension (renin) [1]. Proteases represent the class of enzymes which occupy a pivotal position with respect to their physiological roles as well as their commercial applications. They perform both degradative and synthetic functions. Since they are physiologically necessary for living organisms, proteases occur ubiquitously in a wide diversity of sources such as plants, animals, and microorganisms. Microbes are an attractive source of proteases owing to the limited space required for their cultivation and their ready susceptibility to genetic manipulation. Proteases play a critical role in many physiological and pathophysiological processes. There is a renaissance of interest in using proteolytic enzymes as targets for developing therapeutic agents [2]. $C$. albicans is the most common fungal pathogen of humans and has developed an extensive repertoire of putative virulence mechanisms that allows successful colonization and infection of the host under suitable predisposing conditions. Extracellular protolytic activity plays a central role in Candida pathogenicity and is produced by a family of 10 secreted aspartyl proteinases (Sap proteins). Although the consequences of proteinase secretion during human infections are not precisely known, in vitro, animal, and human studies have implicated the proteinases in C. albicans virulence in one of the following seven ways: (i) correlation between Sap production in vitro and Candida virulence, (ii) degradation of human proteins and structural analysis in determining Sap substrate specificity, (iii) association of Sap production with other virulence processes of C. albicans, (iv) Sap protein production and Sap immune responses in animal and human infections, (v) Sap gene expression during Candida infections, (vi) modulation of $C$. albicans virulence by aspartyl proteinase inhibitors, and (vii) the use of Sap-disrupted mutants to analyze $C$. albicans virulence. Sap proteins fulfill a number of specialized functions during the infective process, which include the simple role of digesting molecules for nutrient acquisition, digesting or distorting host cell membranes to facilitate adhesion and tissue invasion, and digesting cells and molecules of the host immune system to avoid or resist antimicrobial attack by the host [3].

The present study describes the chelation behavior of Schiff's base (A1), derived from the condensation of 2hydroxy acetophenone with hydrazine hydrate, towards some transition elements; which may help in more understanding of the mode of chelation towards metals.
For this purpose, the complexes of $\mathrm{Mn}(\mathrm{II}), \mathrm{Fe}(\mathrm{III}), \mathrm{Co}(\mathrm{II})$, $\mathrm{Ni}(\mathrm{II}), \mathrm{Cu}(\mathrm{II}), \mathrm{Zn}$ (II), $\mathrm{Hg}$ (II), $\mathrm{Ce}(\mathrm{IV})$, and $\mathrm{UO}_{2}$ (II) ions with $\mathrm{H}_{2} \mathrm{~L}$ are studied in solution and in solid states. The structures of the studied complexes are elucidated using elemental analyses, FT-IR, ${ }^{1} \mathrm{H}-\mathrm{NMR}$, solid reflectance, magnetic moment, molar conductance, and thermal analyses (TGA, DTGA, and DTA) measurements. The biological activity of the parent Schiff base and its metal complexes had been practically and theoretically studied.

\section{Experimental}

\subsection{Materials and reagents}

All chemicals used in this study were of the analytical reagent grade and of highest purity available. They included $\mathrm{Cu}$ (II) chloride (Sigma-Aldrich, MO, USA); $\mathrm{Co}(\mathrm{II})$ and Ni(II) chloride hexahydrates (BDH Middle East LLC, Dubai, UAE); ferric chloride hexahydrate (BDH Prolabo Chemicals, Lyndhurst, South Africa); Zn(II) chloride (Ubichem, Worcestershire, UK); $\mathrm{Hg}$ (II) chloride, $\mathrm{Ce}(\mathrm{IV})$ sulphate, and $\mathrm{UO}_{2}$ (II) nitrate (Sigma). Organic solvents used included absolute ethyl alcohol and dimethylformamide (DMF). These solvents were spectroscopic pure from BDH. Distilled water collected from all glass equipments was used in all preparations.

\subsection{Synthesis of metal complexes}

The metal complexes of A1 were prepared by the addition of hot solution $\left(60^{\circ} \mathrm{C}\right)$ of the appropriate metal ion in absolute ethanol $(15 \mathrm{~mL})$ to the hot solution $\left(60^{\circ} \mathrm{C}\right)$ of the organic ligand $(0.3 \mathrm{~g} \mathrm{~A} 1)$ in ethanol and $\mathrm{DMF}(15 \mathrm{~mL})$. The resulting mixture was heated with stirring to evaporate all the solvents to get precipitate. The purified precipitates by washing with hot ethanol-water mixture (1:1) were dried and weighed to calculate the yield. All the above steps were repeated for all the selected transition metal complexes.

\subsection{Instruments and measurements}

The molar conductance of metal complexes solutions in DMF $\left(10^{-3} \mathrm{M}\right)$ was measured using Sybron-Barnstead conductometer (Meter-PM, $E=3,406$ ). Elemental microanalyses of the separated solid chelates for $\mathrm{C}, \mathrm{H}, \mathrm{N}$, and $\mathrm{S}$ were performed in the microanalytical center at Cairo University. The analyses were repeated twice to check the accuracy of the data. Infrared spectra were recorded on a Perkin-Elmer FT-IR type 1650 spectrophotometer in the region 4,000-400 $\mathrm{cm}^{-1}$ as $\mathrm{KBr}$ disks. The ${ }^{1} \mathrm{H}-\mathrm{NMR}$ spectra were recorded with a JEOL EX-270 MHz in DMSO-d6 as solvent, where the chemical shifts were determined relative to the solvent peaks. The diffused reflectance spectra of some of these complexes were measured on a Shimadzu 3101 PC spectrophotometer. The molar magnetic susceptibility was measured on powdered samples using Faraday method. The diamagnetic corrections were made 
by Pascal's constant and $\mathrm{Hg}\left[\mathrm{Co}(\mathrm{SCN})_{4}\right]$ was used as a calibrant. The magnetic data for the background of the sample holder were corrected. The thermal analyses (TG, DTG, and DTA) were carried out in dynamic nitrogen atmosphere $\left(20 \mathrm{~mL} \mathrm{~min}^{-1}\right)$ with a heating rate of $10^{\circ} \mathrm{C} \mathrm{min}{ }^{-1}$ using Shimadzu TG-60H and DTA-60H thermal analyzers.

\subsection{Biological activity}

The tests were done in the Regional Center for Mycology and Biotechnology (RCMB) Culture Collection. These tests were done using the diffusion agar technique. Spore suspension $\left(0.5 \mathrm{~mL}, 10^{-6}-10^{-7}\right.$ spore $\left.\mathrm{mL}^{-1}\right)$ of each of the investigated organisms was added to a sterile agar medium just before solidification, then poured into sterile Petri dishes $(6 \mathrm{~cm}$ in diameter) and left to solidify. Using sterile cork borer ( $6 \mathrm{~mm}$ in diameter), three holes (wells) were made into each dish, and then $0.1 \mathrm{~mL}$ of the test compound dissolved in DMF $\left(100 \mathrm{mg} \mathrm{mL}^{-1}\right)$ was poured into these holes. The dishes were incubated at $37^{\circ} \mathrm{C}$ for $48 \mathrm{~h}$ where clear or inhibition zones were detected around each hole. DMF $(0.1 \mathrm{~mL})$ was used as a control under the same conditions. By subtracting the diameter of the inhibition zone resulting with DMF from that obtained from each metal complex or the free Schiff base, antibacterial activities were calculated as a mean of three replicates. MIC50 was determined and was defined as the lowest compound concentration that inhibits growth by $50 \%$.

\subsection{Molecular docking}

Docking study was performed using the MOE 2014.09 software. Downloading the crystal structure of the secreted aspartic proteinase 2 (Sap2) PDB ID (1EAG) was carried out from protein data bank website. Regularization and optimization for protein and ligand were performed. Determination of the essential amino acids in binding site was carried out and compared with that present in literature. The performance of the docking method was evaluated by redocking crystal ligand into the assigned active Sap2 to determine the root-mean-square deviation (RMSD) value. Interactive docking was carried out for all the conformers of interesting compound to the selected active site. Each docked compound was assigned a score according to its fit in the ligand binding pocket (LBP) and its binding mode.

\subsection{Bioactivity and ADME toxicity}

Optimization of the ADME (absorption, distribution, metabolism, and excretion) properties of the drug molecule is often the most difficult and challenging part of the whole drug discovery process. The ADME profile will also have a major impact on the likelihood of success of a drug.
Keeping an eye of molecular properties throughout the drug discovery process is a critical aspect of the process, with the focus at different stages. The hunt for new drugs can be divided into two stages: discovery and development. Drug discovery includes generating a hypothesis of the target receptor for a particular disorder and screening the in vitro and/or in vivo biological activities of the new drug candidates. Drug development involves the assessment of efficacy and toxicity of the new drug candidates.

To aid in a discovery program, accurate data on pharmacokinetics and metabolism must be available as early as possible as it eventually contributes to the final success or failure of the compound. The initiation of early absorption, distribution, metabolism, and excretion (ADME) screening has dramatically decreased the proportion of compounds failing in clinical trials. The main aim of preclinical ADME is to eliminate weak drug candidates in the early stages of drug development which allow resources to be focused on potential drug candidates. Undesirable pharmacokinetic properties, such as poor absorption, too long or too short halflife ( $\mathrm{t} 1 / 2)$, and extensive first-pass metabolism, majorly contribute to the failure of many drug candidates in early stages of drug development programs. To be successful, a drug candidate needs to possess good bioavailability and a desirable half-life $(\mathrm{t} 1 / 2)$.

\section{Results and discussion}

\subsection{Characterization of Schiff-base (A1) metal complexes}

The ligand under investigation (A1) is a novel Schiff base; it has a general formula $\left(\mathrm{C}_{8} \mathrm{H}_{10} \mathrm{~N}_{2} \mathrm{O}\right)$, mole mass $=150$, and a structural formula (Figure 1).

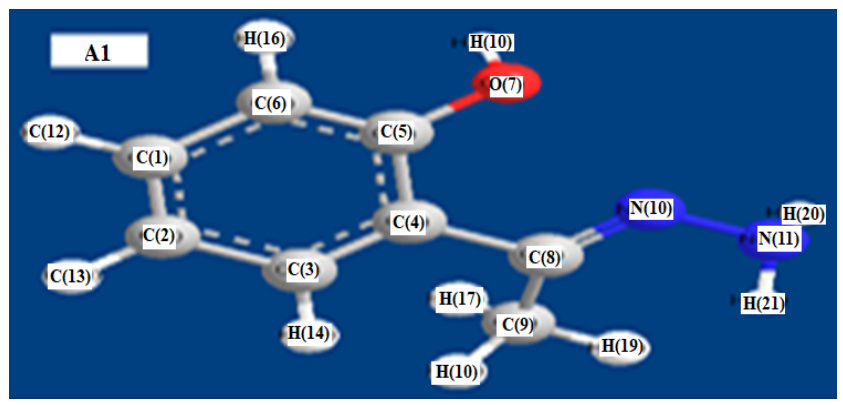

Figure 1: Stereo structure of A1 and its numbering system.

Metal complexes of this novel Schiff base were obtained through the reaction between metal ions and $\mathrm{H}_{2} \mathrm{~L}$ ligand at 1:2 or 1:3 (M:L) ratio. The synthesized Schiff-base ligand and its complexes are very stable at room temperature. The metal complexes are commonly soluble in DMF and dimethyl sulfoxide (DMSO). The elemental analyses, color, and melting points of metal complexes are presented in Table 1. 
Table 1: The analytical data of the proposed stoichiometry of the complexes.

\begin{tabular}{|c|c|c|c|c|c|c|c|}
\hline No & Mol. formula/general formula & Color & M.P. & Mol. Wt. & $\begin{array}{l}\text { C\% calcd. } \\
\text { (found) }\end{array}$ & $\begin{array}{l}\mathrm{H} \% \text { calcd. } \\
\text { (found) }\end{array}$ & $\begin{array}{l}\text { N\% calcd. } \\
\text { (found) }\end{array}$ \\
\hline 1 & $\begin{array}{l}\mathrm{Mn}\left(\mathrm{C}_{8} \mathrm{H}_{9} \mathrm{~N}_{2} \mathrm{O}\right)_{2} \\
\mathrm{Mn}(\mathrm{L})_{2}\end{array}$ & Pale yellow & 220 & 352.94 & $\begin{array}{c}54.40 \\
(54.60) \\
\end{array}$ & $\begin{array}{c}5.10 \\
(5.82) \\
\end{array}$ & $\begin{array}{c}15.86 \\
(15.81)\end{array}$ \\
\hline 2 & $\begin{array}{l}\mathrm{Cr}\left(\mathrm{C}_{8} \mathrm{H}_{9} \mathrm{~N}_{2} \mathrm{O}\right)_{3} \\
\mathrm{Cr}(\mathrm{L})_{3}\end{array}$ & Greenish yellow & 205 & 498.996 & $\begin{array}{c}57.71 \\
(57.06)\end{array}$ & $\begin{array}{c}5.41 \\
(6.00)\end{array}$ & $\begin{array}{c}16.83 \\
(16.77)\end{array}$ \\
\hline 3 & $\begin{array}{l}\mathrm{Fe}\left(\mathrm{C}_{8} \mathrm{H}_{9} \mathrm{~N}_{2} \mathrm{O}\right)_{3} \\
\mathrm{Fe}(\mathrm{L})_{3}\end{array}$ & Brownish yellow & 108 & 502.84 & $\begin{array}{c}57.27 \\
(57.27) \\
\end{array}$ & $\begin{array}{c}5.37 \\
(5.25) \\
\end{array}$ & $\begin{array}{c}16.70 \\
(16.62) \\
\end{array}$ \\
\hline 4 & $\begin{array}{l}\mathrm{Co}\left(\mathrm{C}_{8} \mathrm{H}_{9} \mathrm{~N}_{2} \mathrm{O}\right)_{2} \\
\mathrm{Co}(\mathrm{L})_{2}\end{array}$ & Yellow & 210 & 356.93 & $\begin{array}{r}53.79 \\
(53.50) \\
\end{array}$ & $\begin{array}{c}5.04 \\
(5.15) \\
\end{array}$ & $\begin{array}{c}15.69 \\
(15.80) \\
\end{array}$ \\
\hline 5 & $\begin{array}{l}\mathrm{Ni}\left(\mathrm{C}_{8} \mathrm{H}_{9} \mathrm{~N}_{2} \mathrm{O}\right)_{2} \cdot 2 \mathrm{H}_{2} \mathrm{O} \\
\mathrm{Ni}(\mathrm{L})_{2} \cdot 2 \mathrm{H}_{2} \mathrm{O}\end{array}$ & Greenish yellow & 207 & 392.69 & $\begin{array}{c}48.89 \\
(48.70) \\
\end{array}$ & $\begin{array}{c}5.60 \\
(5.61)\end{array}$ & $\begin{array}{c}14.26 \\
(14.50)\end{array}$ \\
\hline 6 & $\begin{array}{l}\mathrm{Cu}\left(\mathrm{C}_{8} \mathrm{H}_{9} \mathrm{~N}_{2} \mathrm{O}\right)_{2} \cdot 2 \mathrm{H}_{2} \mathrm{O} \\
\mathrm{Cu}(\mathrm{L})_{2} \cdot 2 \mathrm{H}_{2} \mathrm{O}\end{array}$ & Gray yellow & 220 & 397.55 & $\begin{array}{c}48.29 \\
(48.70)\end{array}$ & $\begin{array}{c}5.53 \\
(5.93) \\
\end{array}$ & $\begin{array}{c}14.08 \\
(14.79)\end{array}$ \\
\hline 9 & $\begin{array}{l}\mathrm{Cd}\left(\mathrm{C}_{8} \mathrm{H}_{9} \mathrm{~N}_{2} \mathrm{O}\right)_{2} \\
\mathrm{Cd}(\mathrm{L})_{2}\end{array}$ & Pale yellow & $>300$ & 410.41 & $\begin{array}{l}46.78 \\
46.60 \\
\end{array}$ & $\begin{array}{l}4.39 \\
4.41\end{array}$ & $\begin{array}{l}13.64 \\
13.55\end{array}$ \\
\hline 10 & $\begin{array}{l}\mathrm{Zn}\left(\mathrm{C}_{8} \mathrm{H}_{9} \mathrm{~N}_{2} \mathrm{O}\right)_{2} \\
\mathrm{Zn}(\mathrm{L})_{2}\end{array}$ & Yellow & 205 & 363.39 & $\begin{array}{c}52.84 \\
(52.80)\end{array}$ & $\begin{array}{c}4.95 \\
(5.00)\end{array}$ & $\begin{array}{c}15.41 \\
(15.19)\end{array}$ \\
\hline 11 & $\begin{array}{l}\mathrm{Hg}\left(\mathrm{C}_{8} \mathrm{H}_{9} \mathrm{~N}_{2} \mathrm{O}\right)_{2} \\
\mathrm{Hg}(\mathrm{L})_{2}\end{array}$ & Yellow & 198 & 498.5 & $\begin{array}{c}38.51 \\
(38.98) \\
\end{array}$ & $\begin{array}{c}3.61 \\
(3.55) \\
\end{array}$ & $\begin{array}{c}11.23 \\
(11.34) \\
\end{array}$ \\
\hline 12 & $\begin{array}{l}\mathrm{Ce}\left(\mathrm{C}_{8} \mathrm{H}_{9} \mathrm{~N}_{2} \mathrm{O}\right)_{3} \\
\mathrm{Ce}(\mathrm{L})_{3}\end{array}$ & Yellow & $218-221$ & 587.12 & $\begin{array}{r}49.05 \\
(50.76) \\
\end{array}$ & $\begin{array}{r}4.60 \\
(4.59) \\
\end{array}$ & $\begin{array}{c}14.26 \\
(14.04) \\
\end{array}$ \\
\hline 13 & $\begin{array}{l}\mathrm{UO}_{2}\left(\mathrm{C}_{8} \mathrm{H}_{9} \mathrm{~N}_{2} \mathrm{O}\right)_{2} \mathrm{H}_{2} \mathrm{O} \\
\mathrm{UO}_{2}(\mathrm{~L})_{2} \cdot \mathrm{H}_{2} \mathrm{O}\end{array}$ & Yellow & 230 & 586.0 & $\begin{array}{c}38.22 \\
(38.54) \\
\end{array}$ & $\begin{array}{c}3.41 \\
(3.64) \\
\end{array}$ & $\begin{array}{c}9.55 \\
(9.60) \\
\end{array}$ \\
\hline
\end{tabular}

\subsection{1. ${ }^{1} H-N M R$ and ${ }^{13} C-N M R$}

The HNMR spectra of ligand previously published [23] show a sharp band at $8.4 \mathrm{ppm}$ and $8.5 \mathrm{ppm}$ which may be assigned to the protons of two azomethine groups $(-\mathrm{CH}=\mathrm{N}-)$, respectively. These signals are completely shifted in the Zn complex (Figure 2), indicating that azomethine groups are shared in chelation process. However, a single and multiple bands at $4.9 \mathrm{ppm}$ and 6.4-8 ppm attributed to methylene and the aromatic protons in the free A1 ligand are shifted to $4.3 \mathrm{ppm}$ and $6.2-7.6 \mathrm{ppm}$, respectively, which indicates the coordination of ligand to $\mathrm{Zn}$ (II) ion. ${ }^{13} \mathrm{C}-\mathrm{NMR}$ refers to the appeal of signal of chemical shift 157.2 of $\mathrm{C}-\mathrm{OH}$ of phenolic group and the signal at 143.3 of $-\mathrm{CH}=\mathrm{N}-$ in the free ligand $\mathrm{A} 1$. These signals are shifted to other values of chemical shifts: 168.8 and 158.3; which may refer to the sharing of these groups in complex formation.

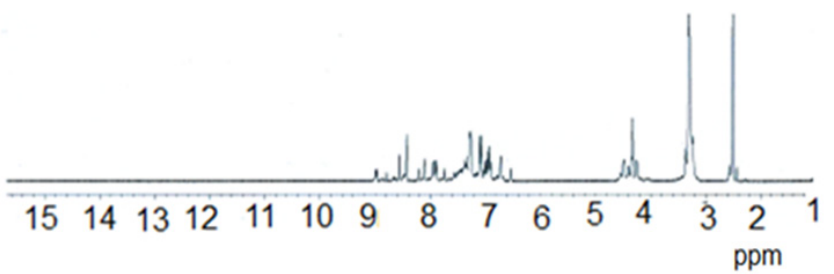

Figure 2: The ${ }^{1} \mathrm{H}-\mathrm{NMR}$ of $\mathrm{Zn}(\mathrm{II})-\mathrm{A} 1$-complex.

\subsubsection{Thermal behavior of A1-metal complexes and ther- modynamic calculations}

Thermal analyses' results of the investigated Schiff-base metal (II)/(III) complexes are given in Table 2.

\subsubsection{Molar conductance measurements}

Conductivity measurements in nonaqueous solutions have been used in structural studies of metal chelates within the limits of their solubility. They provide a method of testing the degree of ionization of the complexes: the molar ions that a complex liberates in solution, the higher will be its molar conductivity and vice versa. The molar conductivities of $10^{-3}$ molar solutions of the metal chelates at $25 \pm 2{ }^{\circ} \mathrm{C}$ are measured. The molar conductance values (110-125 $\Omega^{-1} \mathrm{~mol}^{-1} \mathrm{~cm}^{2}$ ) of the $\mathrm{Co}(\mathrm{II}), \mathrm{Ni}(\mathrm{II}), \mathrm{Cu}$ (II), and $\mathrm{Zn}$ (II) complexes with A1 ligand are considered as 1:2 electrolytes as confirmed by the given proposed general formulae of these complexes. In addition, $\mathrm{Fe}$ (III) and $\mathrm{Ce}(\mathrm{IV})-\mathrm{A} 1$ complexes have molar conductance value of 250-266 $\Omega^{-1} \mathrm{~mol}^{-1} \mathrm{~cm}^{2}$, indicating their ionic nature and they are considered as 1:3 electrolytes [22].

\subsubsection{IR spectral studies}

The IR spectra of the complexes are compared with the free ligand [23] in order to determine the coordination sites that may involve in chelation. The spectrum of free ligand shows a band in the region $1637 \mathrm{~cm}^{-1}$ characteristics of the azomethine stretching mode. This band was shifted towards 
Table 2: TG and DTG analysis of A1-complexes.

\begin{tabular}{|c|c|c|c|c|c|c|c|c|}
\hline Complex & Stage & $\begin{array}{c}\text { Decom. temp. range } \\
\left({ }^{\circ} \mathrm{C}\right)\end{array}$ & $\begin{array}{c}\mathrm{Ts} \\
\left({ }^{\circ} \mathrm{C}\right)\end{array}$ & $\begin{array}{c}\mathrm{E} \\
\left(\mathrm{KJ} \mathrm{mol}^{-1}\right)\end{array}$ & $\begin{array}{c}\mathrm{A} \\
\left(\mathrm{s}^{-1}\right)\end{array}$ & $\begin{array}{c}\Delta S^{*} \\
\left(\mathrm{~J} \mathrm{~mol}^{-1}\right)\end{array}$ & $\begin{array}{c}\Delta H^{*} \\
\left(\mathrm{KJ} \mathrm{mol}^{-1}\right)\end{array}$ & $\begin{array}{c}\Delta G^{*} \\
\left(\mathrm{KJ} \mathrm{mol}^{-1}\right)\end{array}$ \\
\hline \multirow{2}{*}{$\operatorname{Mn}(\mathrm{L})_{2}$} & 1 & $200-314$ & 299.56 & 89.00 & $1.994 E+06$ & -124.4 & 469.20 & 123.76 \\
\hline & 2 & $450-520$ & 499.10 & 1126.78 & $9.53 E+78$ & 1262.98 & 1122.63 & 491.1 \\
\hline \multirow{4}{*}{$\mathrm{Fe}(\mathrm{L})_{3}$} & 1 & $180-200$ & 193.27 & 450.1 & $3.878 E+50$ & 727.3 & 448.6 & 308.1 \\
\hline & 2 & $200-260$ & 262.95 & 426.2 & $1.07 E+45$ & 618.3 & 424.0 & 261.4 \\
\hline & 3 & $280-460$ & 371.09 & 576.1 & $2.024 E+52$ & 755.5 & 573.3 & 315.6 \\
\hline & 4 & $460-600$ & 510.12 & 1111.8 & $6.58 E+76$ & 1221.4 & 1107.6 & 484.5 \\
\hline \multirow{2}{*}{$\mathrm{Co}(\mathrm{L})_{2}$} & 1 & $220-324$ & 299.56 & 157.07 & $1.250 E+14$ & 24.90 & 154.58 & 147.11 \\
\hline & 2 & $370-450$ & 370 & 258.1 & $8.49 E+18$ & 115.03 & 254.8 & 208.7 \\
\hline \multirow{4}{*}{$\mathrm{Ni}(\mathrm{L})_{2} 2 \mathrm{H}_{2} \mathrm{O}$} & 1 & $70-120$ & 86.97 & 6.57 & $1.156 E+5$ & -137.80 & 5.849 & 17.84 \\
\hline & 2 & $130-200$ & 160.97 & 410.77 & $6.11 E+50$ & 732.60 & 409.24 & 291.65 \\
\hline & 3 & $200-320$ & 293.32 & 464.789 & $1.87 E+48$ & 679.50 & 462.35 & 263.05 \\
\hline & 4 & $450-600$ & 500.1 & 1179.62 & $8.42 E+77$ & 1242.97 & 1109.04 & 487.52 \\
\hline \multirow{4}{*}{$\mathrm{Cu}(\mathrm{L})_{2} \cdot 2 \mathrm{H}_{2} \mathrm{O}$} & 1 & $170-210$ & 200.49 & 410.9 & $1.046 E+46$ & 539.5 & 409.2 & 281.1 \\
\hline & 2 & $210-260$ & 230.80 & 406.1 & $7.51 E+51$ & 750.44 & 494.1 & 320.9 \\
\hline & 3 & $260-440$ & 313.46 & 117.8 & $2.283 E+09$ & -66.2 & 115.2 & 135.9 \\
\hline & 4 & $440-520$ & 460.45 & 1222.7 & $3.37 E+85$ & 1389.03 & 1218.8 & 579.3 \\
\hline \multirow{2}{*}{$\mathrm{Zn}(\mathrm{L})_{2}$} & 1 & $200-330$ & 280.09 & 471.53 & $1.588 E+49$ & 697.6 & 469.20 & 273.81 \\
\hline & 2 & $500-650$ & 574.91 & 1179.62 & $1.81 E+77$ & 1230.03 & 1175.46 & 561.05 \\
\hline \multirow{2}{*}{$\mathrm{Ce}(\mathrm{L})_{3}$} & 1 & $200-300$ & 157.83 & 282.68 & $6.921 E+36$ & 455.70 & 281.36 & 207.86 \\
\hline & 2 & $300-400$ & 347.74 & 647.85 & $3.83 E+56$ & 837.18 & 644.95 & 353.83 \\
\hline \multirow{3}{*}{$\mathrm{UO}_{2}(\mathrm{~L})_{2} \mathrm{H}_{2} \mathrm{O}$} & 1 & $175-200$ & 182.62 & 477.7 & $1.992 E+54$ & 798.8 & 476.16 & 330.28 \\
\hline & 2 & $227-260$ & 230.17 & 95.67 & $1.28 E+08$ & -87.56 & 93.76 & 113.91 \\
\hline & 3 & $350-540$ & 466.45 & 773.09 & $1.384 E+62$ & 941.2 & 769.21 & 330.21 \\
\hline
\end{tabular}

lower frequencies in the spectra of its metal complexes (1605-1623 $\mathrm{cm}^{-1}$ ) (Table 3). This phenomenon appears to be due to the coordination of azomethine nitrogen to the metal ion [23,24]. New bands are found in the spectra of complexes in the regions $608-648$ and $498-601 \mathrm{~cm}^{-1}$, which are assigned to $(\mathrm{M}-\mathrm{O}),(\mathrm{M}-\mathrm{N})$, respectively, and stretching vibrations. Therefore, from the IR spectra it is concluded that A1 Schiff's base is tetra dentate ligand with NNOO coordination sites with one or $2 \mathrm{H}_{2} \mathrm{O}$ molecules of crystallization present in the moiety of some complexes. Therefore, from these data the proposed structural formulae for these complexes can be given by Figure 3 .

\subsubsection{Magnetic susceptibility and electronic spectral stud- ies}

The diffused reflectance spectral data of the complexes, position of bands, and their transitions assignments are of particular importance as they are highly dependent on the geometry of the molecule. From the diffused reflectance spectrum of the Fe(III) complex, the bands at $14,096 \mathrm{~cm}^{-1}$, $18,625 \mathrm{~cm}^{-1}$, and $24,585 \mathrm{~cm}^{-1}$ may be assigned to the $6 \mathrm{~A} 1 \mathrm{~g} \rightarrow \mathrm{T} 2 \mathrm{~g}(\mathrm{G})$ and $6 \mathrm{~A} 1 \mathrm{~g} \rightarrow 5 \mathrm{~T} 1 \mathrm{~g}$ transitions in octahedral geometry of the complex [25]. The spectrum shows also a band at $27,777 \mathrm{~cm}^{-1}$ which may be attributed to ligand to metal charge transfer. This geometry is further supported by its magnetic susceptibility value (3.8 BM) [25, 26, 27].

The diffused reflectance spectrum of the $\mathrm{Cu}$ (II) complex displayed the $\mathrm{d}-\mathrm{d}$ transition band in the region $13,606 \mathrm{~cm}^{-1}$ which is due to $2 \mathrm{Eg} \rightarrow 2 \mathrm{~T} 2 \mathrm{~g}$ transition. This $\mathrm{d}-\mathrm{d}$ transition band strongly favors a distorted octahedral geometry around the metal ion. This geometry is further supported by its magnetic susceptibility value (1.5 BM) [25,26,27].

The spectrum of $\mathrm{Ni}(\mathrm{II})$ complex displayed three $\mathrm{d}-\mathrm{d}$ bands at $13,150 \mathrm{~cm}^{-1}, 14,749 \mathrm{~cm}^{-1}$, and $23,310 \mathrm{~cm}^{-1}$. These bands correspond to $3 \mathrm{~A} 2 \mathrm{~g}(\mathrm{~F}) \rightarrow 3 \mathrm{~T} 2 \mathrm{~g}(\mathrm{~F}), 3 \mathrm{~A} 2 \mathrm{~g}$ $(\mathrm{F}) \rightarrow 3 \mathrm{~T} 1 \mathrm{~g} \quad(\mathrm{~F})$, and $3 \mathrm{~A} 2 \mathrm{~g} \quad(\mathrm{~F}) \rightarrow 3 \mathrm{~T} 1 \mathrm{~g} \quad(\mathrm{P})$ transitions, respectively, being characteristic of an octahedral geometry. This geometry is further supported by its magnetic susceptibility value $(2.4 \mathrm{BM})[25,26,27]$.

Diffused reflectance spectrum of $\mathrm{Co}$ (II) complex displayed the $\mathrm{d}-\mathrm{d}$ transition bands in the regions $15,017 \mathrm{~cm}^{-1}$, $16,723 \mathrm{~cm}^{-1}$, and $23,566 \mathrm{~cm}^{-1}$ which are assigned to $4 \mathrm{~T} 1 \mathrm{~g}(\mathrm{~F}) \rightarrow 4 \mathrm{~A} 2 \mathrm{~g} \quad(\mathrm{~F}), 4 \mathrm{~T} 1 \mathrm{~g} \quad(\mathrm{~F}) \rightarrow 4 \mathrm{~T} 2 \mathrm{~g}(\mathrm{~F})$, and $4 \mathrm{~T} 1 \mathrm{~g}$ $(\mathrm{F}) \rightarrow 4 \mathrm{~T} 1 \mathrm{~g}$ (P) transitions, respectively. The transitions correspond to the octahedral geometry of the complex which is also supported by its magnetic susceptibility value (3.06 BM) [25, 26, 27, 28].

The proposed structural formulae of the given complexes depending upon the above data and discussion are given in Figure 3.

\subsection{Biological activity explanation}

Schiff's bases are important class of compounds in medicinal and pharmaceutical fields. They show biological applications including antibacterial [29,30,31,32,33] and antitumor activities. Microbes encounter a variety of metal 
Table 3: The FT-IR spectra of $\mathrm{H}_{2} \mathrm{~L}$ (A1) and its metal complexes.

\begin{tabular}{cccccccc}
\hline & $\left(\mathrm{H}_{2} \mathrm{O} / \mathrm{OH}\right)$ & $\mathrm{N}-\mathrm{H}$ & $\mathrm{ArC}-\mathrm{H}$ & $\mathrm{C}=\mathrm{N}$ & $\mathrm{C}-\mathrm{O}$ & $\mathrm{M}-\mathrm{O}$ & $\mathrm{M}-\mathrm{N}$ \\
\hline $\mathrm{H}_{2} \mathrm{~L}(\mathrm{~A} 1)$ & $3403-3305$ & 3287 & 2922 & 1637 & 1374,1244 & - & - \\
\hline $\mathrm{Mn}(\mathrm{L})_{2}$ & $3446-3440$ & 3286 & 2923 & 1604 & 1249 & 648 & 563 \\
\hline $\begin{array}{c}\mathrm{Fe}\left(\mathrm{C}_{8} \mathrm{H}_{9} \mathrm{~N}_{2} \mathrm{O}\right)_{3} \\
\mathrm{Fe}(\mathrm{L})_{3}\end{array}$ & & & 2925 & 1608 & 1246 & 637 & 498 \\
\hline $\mathrm{Co}(\mathrm{L})_{2}$ & & 3287 & 2925 & 1605 & 1244 & 661 & 579 \\
\hline $\mathrm{Ni}(\mathrm{L})_{2} 2 \mathrm{H}_{2} \mathrm{O}$ & $33465-3433$ & & 2924 & 1607 & 1245 & 662 & 497 \\
\hline $\mathrm{Cu}(\mathrm{L})_{2} \cdot 2 \mathrm{H}_{2} \mathrm{O}$ & $3448-3440$ & & 2924 & 1623 & 1200 & 608 & 548 \\
\hline $\mathrm{Zn}(\mathrm{L})_{2}$ & & 3231 & 2924 & 1605 & 1245 & 661 & 575 \\
\hline $\mathrm{Hg}(\mathrm{L})_{2}$ & & 3209 & 2926 & 1605 & 1244 & 662 & 601 \\
\hline $\mathrm{Ce}\left(\mathrm{C}_{8} \mathrm{H}_{9} \mathrm{~N}_{2} \mathrm{O}\right)_{2}$ & & & 2929 & 1608 & 1247 & 662 & 566 \\
$\mathrm{Ce}(\mathrm{L})_{3}$ & & & & & & & \\
\hline $\mathrm{UO} \mathrm{O}_{2}(\mathrm{~L})_{2} \mathrm{H}_{2} \mathrm{O}$ & $3445-3435$ & & & & & & \\
\hline
\end{tabular}<smiles>C/C=C1/C(C)=NN(N)[C@H](Oc2ccccc2/C(C)=N/N)Oc2ccccc21</smiles>

$M=M n(I I), C o(I I), H g(I I)$, and $\mathrm{Zn}(\mathrm{II})$

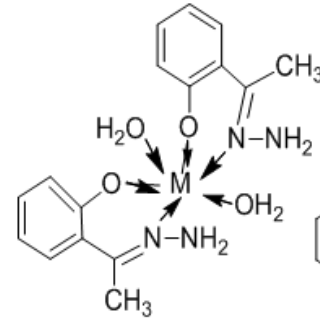

$\mathrm{M}=\mathrm{Ni}(\mathrm{II}), \mathrm{Cu}(\mathrm{II})$

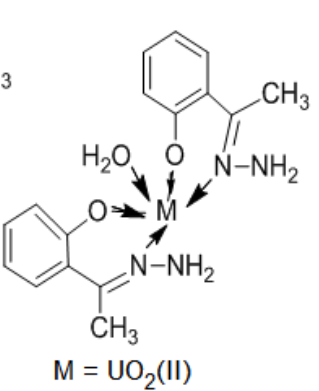

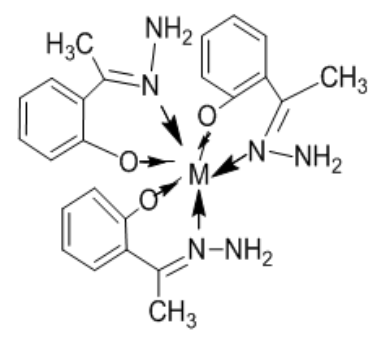

$\mathrm{M}=\mathrm{Fe}(\mathrm{III}), \mathrm{Ce}(\mathrm{IV})$

Figure 3: The proposed structural formulas of A1 complexes.

ions in the environment and interact with them, which is sometimes beneficial or detrimental depending on the chemical/physical nature and oxidation state of the metal ion. The microbes have the ability to bind to metal ions present in the external environment at the cell surface and to transport them into the cell for various intracellular functions. All microbes, prokaryotes or eukaryotes, were employed metal species for structural and/or catalytic functions. Antibacterial activity of the Schiff base and its metal complexes were tested by diffusion agar method [29, 30,31,32,33]. Amphotericin B was used as a reference for antifungal; ampicillin and gentamicin were used as a reference compounds for antibacterial activities. In testing the antibacterial activity of these compounds, more than one test organism was used to increase the chance of detecting antibiotic principles in tested materials. Two types of fungi were used (Aspergillus fumigatus (RCMB 02568) and C. albicans (RCMB 05036)); also two gram-positive (Bacillus subtilis (RCMB 010067) and Streptococcus pneumoniae (RCMB 010010)) and two gram-negative (Escherichia coli RCMB 010052 and Pseudomonas aeruginosa RCMB 010043) bacteria were used as test organisms. The data are expressed in the form of mean \pm SD and minimum inhibitory zone (MIC). Mean zone of inhibition in $\mathrm{mm} \pm$ standard deviation (SD) beyond well diameter $(6 \mathrm{~mm})$ is produced on a range of clinically pathogenic microorganisms using $(5 \mathrm{mg} / \mathrm{mL})$ concentration of tested sample. The data are depicted in Table 4.

From these data it is clear that the standard amphotericin $\mathrm{B}$ has mean zone of inhibition $\pm \mathrm{SD}=23.7 \pm 0.1$ against the fungus A. fumigatus (RCMB 02568); while the biological effects of complexes are ordered as Cu-A1 (20.2 \pm 0.55$)$ $>$ Co-A1 $(18.7 \pm 0.36)>$ Zn-A $1(17.6 \pm 0.58)>\mathrm{Cr}-\mathrm{A} 1$ $(16.8 \pm 0.39)>\mathrm{Ce} \mathrm{A} 1(15.7 \pm 0.36)>\mathrm{Ni}-\mathrm{A} 1(15.7 \pm 0.33)$ $>$ Mn-A1 $(15.3 \pm 0.55)>\mathrm{Hg}-\mathrm{A} 1(13.6 \pm 0.25)>\mathrm{Fe}-\mathrm{A} 1$ $(12.6 \pm 0.25)$. From these data it is also clear that the standard amphotericin $\mathrm{B}$ has mean zone of inhibition $\pm \mathrm{SD}=$ $25.4 \pm 0.1$ against the fungus $C$. albicans (RCMB 05036); while the biological effects of complexes are ordered as $\mathrm{Cu}$ A1 $(19.6 \pm 0.33)>$ Co-A1 $(16.9 \pm 0.27)>$ Cr-A1 (15.9 \pm $0.44)>\mathrm{Zn}-\mathrm{A} 1(15.4 \pm 0.25)>\mathrm{Ni}-\mathrm{A} 1(13.8 \pm 0.25)>\mathrm{Mn}-$ A1 $(13.4 \pm 0.35)>$ Ce-A1 $(13.3 \pm 0.36)>\mathrm{Hg}-\mathrm{A} 1(11.7 \pm$ $0.34)>\mathrm{Fe}-\mathrm{A} 1(11.2 \pm 0.33)$. This survey shows that the A1complexes are of high biological activities as antifungal; in which $\mathrm{Cu}-\mathrm{A} 1$ and $\mathrm{Co}-\mathrm{A} 1$ are the most efficient complexes in a level more or less approaches that of standard.

The biological activity of A1 complexes against grampositive bacteria (B. subtilis (RCMB 010067) and $S$. pneumoniae (RCMB 010010)) refers to the fact that Fe-A1 and Ce-A1 complexes have nondetected (ND) effects. The standard ampicillin has a zone effect of $23.8 \pm 0.2$ on S. pneumoniae (RCMB 010010). The other complexes' 
Table 4: Biological activity of Schiff's base A1 and its metal complexes.

\begin{tabular}{|c|c|c|c|c|c|c|c|c|c|c|c|c|}
\hline $\begin{array}{l}\text { Sample and } \\
\text { tested organism }\end{array}$ & A1 & $\begin{array}{l}\text { Ni-A1 } \\
\text { complex }\end{array}$ & $\begin{array}{l}\text { Co-A1 } \\
\text { complex }\end{array}$ & $\begin{array}{l}\text { Mn-A1 } \\
\text { complex }\end{array}$ & $\begin{array}{l}\text { Zn-A1 } \\
\text { complex }\end{array}$ & $\begin{array}{l}\text { Hg-A1 } \\
\text { complex }\end{array}$ & $\begin{array}{l}\text { CuAc-A1 } \\
\text { complex }\end{array}$ & $\begin{array}{l}\mathrm{CuSO}_{4}-\mathrm{A} 1 \\
\text { complex }\end{array}$ & $\begin{array}{l}\text { Fe-A1 } \\
\text { complex }\end{array}$ & $\begin{array}{l}\text { Ce-A1 } \\
\text { complex }\end{array}$ & $\begin{array}{l}\text { Cr-A1 } \\
\text { complex }\end{array}$ & Standard \\
\hline Fungi & & & & & & & & & & & & Amphotericin \\
\hline $\begin{array}{l}\text { Aspergillus } \\
\text { fumigates } \\
\text { (RCMP02568) }\end{array}$ & & $\begin{array}{l}15.7 \pm \\
0.33\end{array}$ & $\begin{array}{l}18.7 \pm \\
0.36\end{array}$ & $\begin{array}{l}15.3 \pm \\
0.55\end{array}$ & $\begin{array}{l}17.6 \pm \\
0.58\end{array}$ & $\begin{array}{l}13.6 \pm \\
0.25\end{array}$ & $\begin{array}{l}17.3 \pm \\
0.44\end{array}$ & $\begin{array}{l}20.2 \pm \\
0.55\end{array}$ & $\begin{array}{l}12.6 \pm \\
0.25\end{array}$ & $\begin{array}{l}15.7 \pm \\
0.36\end{array}$ & $\begin{array}{l}16.8 \pm \\
0.39\end{array}$ & $\begin{array}{l}23.7 \pm \\
0.10\end{array}$ \\
\hline $\begin{array}{l}\text { C. albicans } \\
\text { (RCMB02568) }\end{array}$ & & $\begin{array}{l}13.8 \pm \\
0.25\end{array}$ & $\begin{array}{l}16.9 \pm \\
0.27\end{array}$ & $\begin{array}{l}13.4 \pm \\
0.35\end{array}$ & $\begin{array}{l}15.4 \pm \\
0.25\end{array}$ & $\begin{array}{l}11.7 \pm \\
0.34\end{array}$ & $\begin{array}{l}16.9 \pm \\
0.25\end{array}$ & $\begin{array}{l}19.6 \pm \\
0.33\end{array}$ & $\begin{array}{l}11.2 \pm \\
0.33\end{array}$ & $\begin{array}{l}13.3 \pm \\
0.36\end{array}$ & $\begin{array}{l}15.9 \pm \\
0.44\end{array}$ & $\begin{array}{l}25.4 \pm \\
0.10\end{array}$ \\
\hline $\begin{array}{l}\text { Gram positive } \\
\text { bacteria }\end{array}$ & & & & & & & & & & & & Ampicillin \\
\hline $\begin{array}{l}\text { Streptococcus } \\
\text { (RCMB010010) }\end{array}$ & 13.8 & $\begin{array}{l}16.9 \pm \\
0.58\end{array}$ & $\begin{array}{l}12.9 \pm \\
0.63\end{array}$ & $\begin{array}{l}17.5 \pm \\
0.44\end{array}$ & $\begin{array}{l}12.3 \pm \\
0.58\end{array}$ & $\begin{array}{l}14.6 \pm \\
0.58\end{array}$ & $\begin{array}{l}16.3 \pm \\
0.55\end{array}$ & $\begin{array}{l}23.8 \pm \\
0.20\end{array}$ & NA & NA & $\begin{array}{l}16.7 \pm \\
0.36\end{array}$ & $\begin{array}{l}23.8 \pm \\
0.20\end{array}$ \\
\hline $\begin{array}{l}\text { Bacillus subtilis } \\
\text { (RCMB010067) }\end{array}$ & 13.1 & $\begin{array}{l}18.2 \pm \\
0.44\end{array}$ & $\begin{array}{l}13.2 \pm \\
0.58\end{array}$ & $\begin{array}{l}19.8 \pm \\
0.63\end{array}$ & $\begin{array}{l}12.7 \pm \\
0.37\end{array}$ & $\begin{array}{l}14.3 \pm \\
0.58\end{array}$ & $\begin{array}{l}18.3 \pm \\
0.25\end{array}$ & $\begin{array}{l}32.4 \pm \\
0.30\end{array}$ & NA & NA & $\begin{array}{l}19.2 \pm \\
0.27\end{array}$ & $\begin{array}{l}32.4 \pm \\
0.30\end{array}$ \\
\hline $\begin{array}{l}\text { Gram negative } \\
\text { bacteria }\end{array}$ & & & & & & & & & & & & Gentamicin \\
\hline $\begin{array}{l}\text { Pseudomonas } \\
\text { aeruginosa } \\
\text { (RCMB010043) }\end{array}$ & 17.9 & NA & NA & NA & NA & NA & $\begin{array}{l}18.3 \pm \\
0.25\end{array}$ & $\begin{array}{l}17.3 \pm \\
0.10\end{array}$ & NA & NA & NA & $\begin{array}{l}17.3 \pm \\
0.10\end{array}$ \\
\hline $\begin{array}{l}\text { Escherichia coli } \\
\text { (RCMB010052) }\end{array}$ & 17.2 & $\begin{array}{l}11.9 \pm \\
0.63\end{array}$ & $\begin{array}{l}10.8 \pm \\
0.44\end{array}$ & $\begin{array}{l}18.9 \pm \\
0.25\end{array}$ & $\begin{array}{l}8.5 \pm \\
0.37\end{array}$ & $\begin{array}{l}9.4 \pm \\
0.44\end{array}$ & $\begin{array}{l}22.6 \pm \\
0.44\end{array}$ & $\begin{array}{l}19.9 \pm \\
0.30\end{array}$ & NA & NA & $\begin{array}{l}13.6 \pm \\
0.36 \\
\end{array}$ & $\begin{array}{l}19.9 \pm \\
0.30\end{array}$ \\
\hline
\end{tabular}

A1: is benzoylhydrazone Schiff's base of IUPAC name (2(1-hydrazonoethyl) phenol); NA means no activity, data are expressed in the form of mean \pm standard deviation (SD).

effects on S. pneumoniae (RCMB 010010) are ordered in their increasing effect: $\mathrm{Cu}-\mathrm{A} 1(23.8 \pm 0.20)>\mathrm{Mn}-\mathrm{A} 1$ $(17.5 \pm 0.44)>\mathrm{Ni}-\mathrm{A} 1(16.9 \pm 0.58)>\mathrm{Cr}-\mathrm{A} 1(16.7 \pm 0.36)$ $>\mathrm{Hg}-\mathrm{A} 1(14.6 \pm 0.58)>\mathrm{Co}-\mathrm{A} 1(12.9 \pm 0.63)>\mathrm{Zn}-\mathrm{A} 1$ $(12.3 \pm 0.58)$. The standard ampicillin has a zone effect of $32.4 \pm 0.4$ on B. subtilis (RCMB 010067). The A1 complexes' effects on B. subtilis (RCMB 010067) are ordered in their increasing effect: $\mathrm{Cu}-\mathrm{A} 1 \quad(32.4 \pm 0.30)$ $>\mathrm{Mn}-\mathrm{A} 1(19.8 \pm 0.63)>\mathrm{Cr}-\mathrm{A} 1(19.2 \pm 0.27)>\mathrm{Ni}-\mathrm{A} 1$ $(18.2 \pm 0.44)>\mathrm{Hg}-\mathrm{A} 1(14.3 \pm 0.58)>\mathrm{Co}-\mathrm{A} 1(13.2 \pm 0.58)$ $>\mathrm{Zn}-\mathrm{A} 1(12.7 \pm 0.37)$. It is clear from these data that the $\mathrm{Cu}-\mathrm{A} 1$ and $\mathrm{Mn}-\mathrm{A} 1$ have the largest biological effects on gram-positive bacteria of both kinds; and $\mathrm{Cu}-\mathrm{A} 1$ complex has a more effect $(32.4 \pm 0.30)$ or of the same order of magnitude $(23.8 \pm 0.20)$ of the ampicillin standard $(23.8 \pm 0.2)$.

The biological activity of A1 complexes on gramnegative bacteria (E. coli (RCMB 010052) and P. aeruginosa (RCMB 010043)) refers to the fact that only copper complex has an effect of $17.3 \pm 0.1$ on $P$. aeruginosa (RCMB 010043) which of the same magnitude of the standard gentamicin having an effect of $(17.3 \pm 0.1)$. The other complexes have ND effects on $P$. aeruginosa (RCMB 010043) and both $\mathrm{Fe}$ and $\mathrm{Ce}$ complexes also have ND effects on E. coli (RCMB 010052). The effects of other complexes on negative bacteria E. coli (RCMB 010052) are in the order $\mathrm{Cu}-\mathrm{A} 1(19.9 \pm 0.30)>\mathrm{Mn}-\mathrm{A} 1(18.9 \pm 0.25)$ $>$ Cr-A1 $(13.6 \pm 0.36)>\mathrm{Ni}-\mathrm{A} 1(11.9 \pm 0.63)>\mathrm{Co}-\mathrm{A} 1$ $(10.8 \pm 0.44)>\mathrm{Hg}-\mathrm{A} 1(9.4 \pm 0.44)>\mathrm{Zn}-\mathrm{A} 1(8.5 \pm 0.37)$.

\subsection{Molecular docking mechanism}

Molecular modeling was done using MOE 2014.09 software package in reckoning or analyzing all parameters to the docked amount or score that might also have a prescribed relationship according to the aspartic proteases inhibition $[34,35,36,37,38,39]$. The results obtained of ligand A1 are given by Table 5 and Figure 4.

Table 5: Ligand interactions report.

\begin{tabular}{|c|c|c|c|c|c|c|}
\hline \multicolumn{7}{|c|}{ 1EAG: hydrolase/hydrolase inhibitor/1EAG } \\
\hline Ligand & & ceptor & Intel & action & Distance & $\mathrm{E}(\mathrm{kcal} / \mathrm{mol})$ \\
\hline O 50 & OD1 & ASP 32 & (A) & H-donor & 3.08 & -0.3 \\
\hline O 50 & OD2 & ASP 32 & (A) & H-donor & 3.63 & -0.5 \\
\hline 52 & OD2 & ASP 218 & (A) & H-donor & 2.97 & 0.3 \\
\hline 50 & OD2 & ASP 218 & (A) & $\mathrm{H}$-acceptor & 2.63 & -2.4 \\
\hline 42 & 6-ring & TYR 84 & (A) & H-pi & 4.46 & -0.2 \\
\hline 6-ring & ND2 & ASN 131 & (A) & pi-H & 4.58 & -0.3 \\
\hline
\end{tabular}

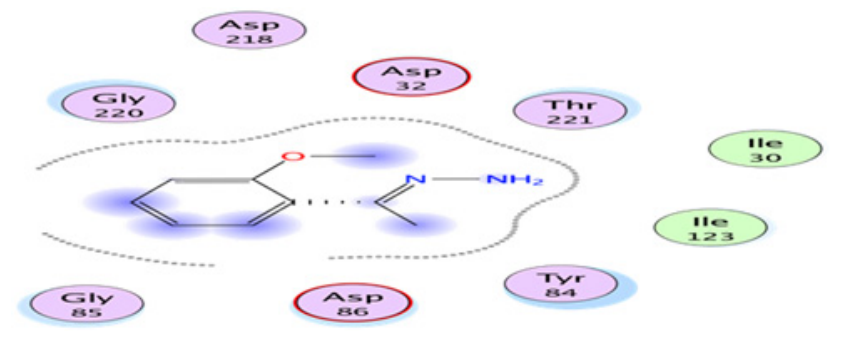

Figure 4: Two dimensional diagram of ligand A1 interactions with the targeting enzymes. 
These results indicate that the parent ligand A1 has no binding energy and it has no affinity for binding with aspartic proteases or any other enzyme of organisms and consequently no inhibition effect to these organisms.

Figures 5-7 show an interaction between the $\mathrm{Cu}-\mathrm{A} 1$ complex with different Candida enzymes.

Figure 5 shows two-dimensional representations showing the hydrogen bond interactions of the interesting compound and the targeting enzyme.

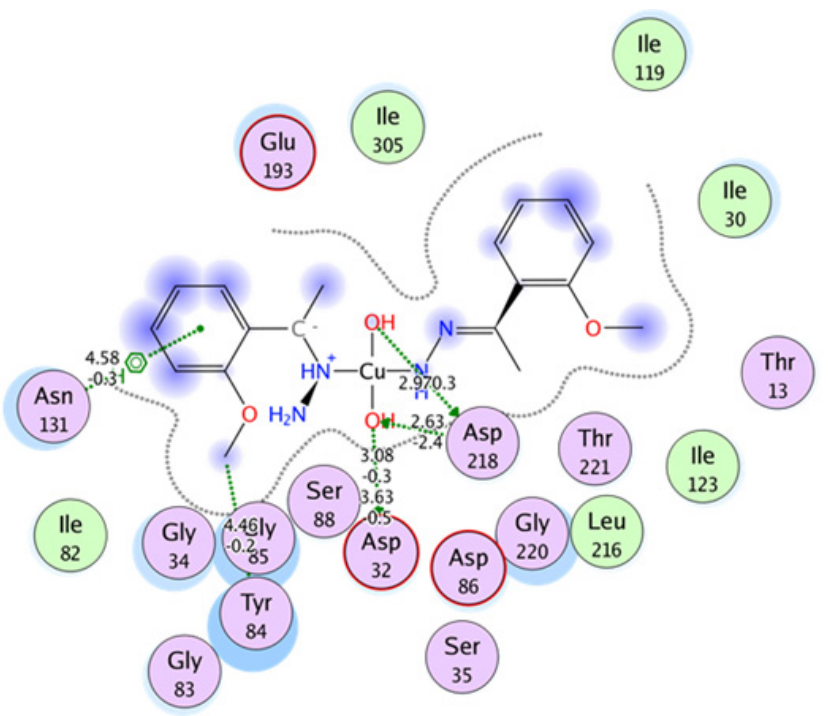

Figure 5: Possible hydrogen bonding between complex A1 and different enzymes of organism.

Figure 6 shows three-dimensional representations of interesting complex pose fitted into the binding pocket of the targeting enzyme.

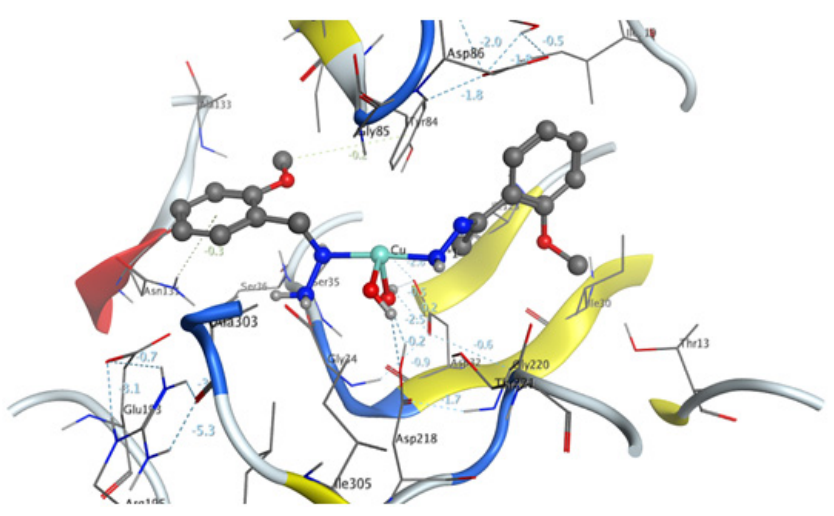

Figure 6: Possible binding of complex A1 with interest organism enzyme.

Figure 7 shows a fitting of the complex molecule into the targeting enzyme's pocket, referring to alternating its conformation and making inhibition to the organisms under test.

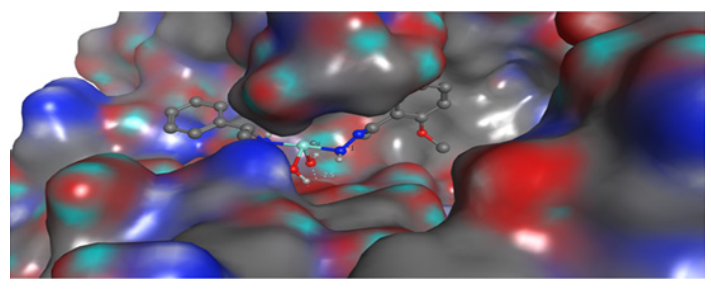

Figure 7: Complex A1 fitted into the binding pocket of the targeting enzyme.

\subsection{Bioactivity and ADME toxicity}

To be successful, a drug candidate needs to possess good bioavailability and a desirable half-life (t1/2). Early ADME provides the necessary data for selecting preclinical candidates, appropriate dosage forms, and formulation. Also, it accelerates the timeline for investigational new drug applications and subsequently new drug application submission to the FDA(4); see Table 6.

\section{Conclusions}

The careful survey of this research leads to the following important conclusions:

(1) preparation, structure investigation, and biological importance of a novel Schiff base (A1) and its metal complexes of $\mathrm{Fe}(\mathrm{III}), \mathrm{Co}(\mathrm{II}), \mathrm{Ni}(\mathrm{II}), \mathrm{Cu}(\mathrm{II}), \mathrm{Mn}(\mathrm{II})$, $\mathrm{Ce}(\mathrm{IV}), \mathrm{UO}_{2}$ (II), $\mathrm{Hg}(\mathrm{II})$, and $\mathrm{Zn}(\mathrm{II})$ are given. It involves elemental, spectroscopic (IR, NMR, and mass spectra), and thermal data (TG and DTA). It gives a structure confirmation of these complexes;

(2) thermal properties and thermal decomposition possibilities of all complexes are investigated and have been evaluated. This study refers to their thermal stability; and this stability may be related the coordination power of metal cation to the remainder part;

(3) it is found that the Schiff-base ligand (A1) and its complexes have an important biological effect on two types of fungi (A. fumigatus (RCMB 02568) and C. albicans (RCMB 05036)); two gram-positive (B. subtilis (RCMB 010067) and S. pneumoniae (RCMB 010010)) and two gram-negative (E. coli (RCMB 010052) and P. aeruginosa (RCMB 010043)).

(4) the A1 complexes are of high biological activities as antifungal, in which $\mathrm{Cu}-\mathrm{A} 1$ and $\mathrm{Co}-\mathrm{A} 1$ approached that of standard;

(5) it is clear from these data that the Cu-A1 and Mn-A1 have the largest biological effects on gram-positive bacteria of both kinds; and $\mathrm{Cu}-\mathrm{A} 1$ complex has a more effect $(32.4 \pm 0.30)$ or of the same order of magnitude $(23.8 \pm 0.20)$ of the ampicillin standard $(23.8 \pm 0.2)$;

(6) the data obtained refers to the fact that only copper complex has an effect of $17.3 \pm 0.1$ on $P$. aeruginosa $(\mathrm{RCMB}$ 010043) which of the same magnitude of the standard gentamicin has effect of $(17.3 \pm 0.1)$; 
Table 6: Bioactivity and ADME toxicity.

\begin{tabular}{|c|c|}
\hline Physical properties & Value of character \\
\hline Formula & $\mathrm{C}_{18} \mathrm{H}_{25} \mathrm{CuN}_{4} \mathrm{O}_{4}$ \\
\hline Molecular weight & $424.96 \mathrm{~g} / \mathrm{mol}$ \\
\hline Num. heavy atoms & 27 \\
\hline Num. arom. heavy atoms & 12 \\
\hline Fraction Csp3 & 0.22 \\
\hline Num. rotatable bonds & 7 \\
\hline Num. H-bond acceptors & 5 \\
\hline Num. H-bond donors & 4 \\
\hline Molar refractivity & 101.11 \\
\hline TPSA & $121.69 \AA^{2}$ \\
\hline \multicolumn{2}{|l|}{ Lipophilicity } \\
\hline $\log P_{o / w}($ iLOGP) & 0.00 \\
\hline $\log P_{o / w}($ XLOGP3) & 2.72 \\
\hline $\log P_{o / w}($ WLOGP) & 2.49 \\
\hline $\log P_{o / w}($ MLOGP $)$ & 0.44 \\
\hline $\log P_{o / w}($ SILICOS-IT $)$ & -0.85 \\
\hline Consensus $\log P_{o / w}$ & 0.96 \\
\hline \multicolumn{2}{|l|}{ Water solubility } \\
\hline $\log S$ (ESOL) & -4.06 \\
\hline Solubility & $3.74 \mathrm{e}-02 \mathrm{mg} / \mathrm{mL} ; 8.81 \mathrm{e}-05 \mathrm{~mol} / \mathrm{L}$ \\
\hline Class & Moderately soluble \\
\hline $\log S$ (Ali) & -4.93 \\
\hline Solubility & $5.00 \mathrm{e}-03 \mathrm{mg} / \mathrm{mL} ; 1.18 \mathrm{e}-05 \mathrm{~mol} / \mathrm{L}$ \\
\hline Class & Moderately soluble \\
\hline $\log S$ (SILICOS-IT) & -4.80 \\
\hline Solubility & $6.69 \mathrm{e}-03 \mathrm{mg} / \mathrm{mL} ; 1.57 \mathrm{e}-05 \mathrm{~mol} / \mathrm{L}$ \\
\hline Class & Moderately soluble \\
\hline \multicolumn{2}{|l|}{ Pharmacokinetics } \\
\hline GI absorption & High \\
\hline BBB permeant & No \\
\hline P-gp substrate & Yes \\
\hline CYP1A2 inhibitor & No \\
\hline CYP2C19 inhibitor & No \\
\hline CYP2C9 inhibitor & No \\
\hline CYP2D6 inhibitor & Yes \\
\hline CYP3A4 inhibitor & Yes \\
\hline $\log K_{p}$ (skin permeation) (5) & $-6.96 \mathrm{~cm} / \mathrm{s}$ \\
\hline \multicolumn{2}{|l|}{ Druglikeness } \\
\hline Lipinski (6) & Yes; 0 violation \\
\hline Ghose (7) & Yes \\
\hline Veber (8) & Yes \\
\hline Egan (9) & Yes \\
\hline Muegge (10) & Yes \\
\hline Bioavailability score (11) & 0.55 \\
\hline \multicolumn{2}{|l|}{ Medicinal chemistry } \\
\hline PAINS (12) & 0 alert \\
\hline Brenk (13) & 2 alerts: hydrazine, imine_1 \\
\hline Leadlikeness (14) & No; 1 violation: $\mathrm{MW}>350$ \\
\hline Synthetic accessibility & 3.74 \\
\hline
\end{tabular}

(7) the other complexes have ND effects on $P$. aeruginosa (RCMB 010043) and both Fe and Ce complexes also have ND effects on E. coli (RCMB 010052).

Acknowledgments This research was supported by the Chemistry Departments at both Cairo and Port Said Universities. Thanks also are presented to the staff at Cairo University for conducting the microanalyses.

Conflict of interest The authors declare that they have no conflict of interest.

\section{References}

[1] R. M. Tada, T. S. Maheta, M. B. Gondaliya, and M. K. Shah, Synthesis and characterization of $\mathrm{Cu}(\mathrm{II}), \mathrm{Ni}(\mathrm{II})$ and $\mathrm{Co}(\mathrm{II})$ based 1, 4-substituted thosemicarbazone complexes, Chem Sci Trans, 2 (2013), 135-140.

[2] N. Manav, N. Gandhi, and N. K. Kaushik, Some tribenzyl Tin(IV) complexes with thiohydrazides and thiodiamines. Synthesis, characterization and thermal studies, J Therm Anal Calorim, 61 (2000), 127-134.

[3] A. K. Mishra, S. B. Mishra, N. Manav, and N. K. Kaushik, Thermal and spectral studies of palladium(II) complexes, J Therm Anal Calorim, 90 (2007), 509-515.

[4] M. N. Patel, P. B. Pansuriya, and M. R. Chhasatia, Synthesis, spectroscopy, thermal and biological aspect of novel sixcoordinated dimeric iron(III) mixed-ligand complexes, Appl Organomet Chem, 22 (2008), 415-426.

[5] M. X. Li, J. Zhou, C. L. Chen, and J. P. Wang, Synthesis, crystal structure and antitumor study of a zinc complex of the 2benzoylpyridine thiosemicarbazone ligand, Z. Naturforsch, 63b (2008), 280-284.

[6] P. Kumar, Synthesis and antimicrobial activities of the 4-chloro$N^{\prime}$-(4-methoxybenzylidene)-benzohydrazide Schiff base promoted by metal(II) ions, The Experiment, 11 (2013), 476-482.

[7] J. Kaizer, Z. Zsigmond, I. Ganszky, G. Speier, M. Giorgi, and M. Réglier, New functional model complexes of intradiolcleaving catechol dioxygenases: properties and reactivity of $\mathrm{Cu}^{I I}(\mathrm{~L})\left(\mathrm{O}_{2} \mathrm{Ncat}\right)$, Inorg Chem, 46 (2007), 4660-4666.

[8] W. Kaim, C. Titze, T. Schurr, M. Sieger, M. Lawson, J. Jordanov, et al., Reactivity of copper(I) complexes with tripodal ligands towards $\mathrm{O}_{2}$ : structures of a precursor $\left[\mathrm{L}^{3} \mathrm{Cu}^{\mathrm{I}}\left(\mathrm{NCCH}_{3}\right)\right]\left(\mathrm{BF}_{4}\right)$, $L^{3}=$ tris(3-isopropyl-4,5-trimethylenepyrazolyl)methane and of its oxidation product $\left[\mathrm{L}^{3} \mathrm{Cu} u^{I I}(\mu-\mathrm{OH})_{2} \mathrm{Cu}^{I I} \mathrm{~L}^{3}\right]\left(\mathrm{BF}_{4}\right)_{2}$ with strong antiferromagnetic spin-spin coupling, Z Anorg Allg Chem, 631 (2005), 2568-2574.

[9] M. G. Abd El Wahed, E. M. Nour, S. Teleb, and S. Fahim, Thermodynamic and thermal investigation of $\mathrm{Co}(\mathrm{II}), \mathrm{Ni}(\mathrm{II})$ and $\mathrm{Cu}(\mathrm{II})$ complexes with adenine, J Therm Anal Calorim, 76 (2004), 343-348.

[10] M. M. Taqui Khan, S. B. Halligudi, S. Shukla, and Z. A. Shaikh, Reductive carbonylation of nitrobenzene to phenylurethane catalyzed by Ru(III)-schiff base complexes, J Mol Catal, 57 (1990), 301-305.

[11] U. Singh, R. Singh, W. Devi, and C. Singh, Schiff base complexes of copper(II) ions: synthesis, characterization and antimicrobial studies, J Chem Pharm Res, 4 (2012), 1130-1135.

[12] M. M. Deshpande, I. H. Seema, and P. A. Kulkarni, Preparation, physical characterization and antimicrobial evaluation of $C o(I I)$, $\mathrm{Ni}(\mathrm{II})$ and $\mathrm{Fe}(\mathrm{III})$ complexes of heterocyclic Schiff bases, Int $\mathrm{J}$ Biol Pharm Res, 4 (2013), 460-464.

[13] G. Kumar, D. Kumar, C. P. Singh, A. Kumar, and V. B. Rana, Synthesis, physical characterization and antimicrobial activity of trivalent metal Schiff base complexes, J Serb Chem Soc, 75 (2010), 629-637.

[14] R. R. Mohamed and A. M. Fekry, Antimicrobial and anticorrosive activity of adsorbents based on chitosan Schiff's base, Int J Electrochem Sci, 6 (2011), 2488-2508.

[15] H. F. Abd El-Halim, M. M. Omar, G. G. Mohamed, and M. A. El-Ela Sayed, Spectroscopic and biological activity studies on tridentate Schiff base ligands and their transition metal complexes, Eur J Chem, 2 (2011), 178-188. 
[16] N. V. Tverdova, E. D. Pelevina, N. I. Giricheva, G. V. Girichev, N. P. Kuzmina, and O. V. Kotova, Molecular structures of $3 d$ metal complexes with various Schiff bases studied by gas-phase electron diffraction and quantum-chemical calculations, J Mol Struct, 1012 (2012), 151-161.

[17] C. Anitha, C. D. Sheela, P. Tharmaraj, and S. Sumathi, Spectroscopic studies and biological evaluation of some transition metal complexes of azo Schiff-base ligand derived from (1-phenyl-2,3-dimethyl-4-aminopyrazol-5-one) and 5-((4chlorophenyl)diazenyl)-2-hydroxybenzaldehyde, Spectrochim Acta A Mol Biomol Spectrosc, 96 (2012), 493-500.

[18] N. Raman, S. Sobha, and A. Thamaraichelvan, A novel bioactive tyramine derived Schiff base and its transition metal complexes as selective DNA binding agents, Spectrochim Acta A Mol Biomol Spectrosc, 78 (2011), 888-898.

[19] R. A. A. Ammar and A. M. A. Alaghaz, Synthesis, spectroscopic characterization and potentiometric studies of a tetradentate $\left[\mathrm{N}_{2} \mathrm{O}_{2}\right]$ Schiff base, $N, N^{\prime}$-bis(2-hydroxybenzylidene)-1,1diaminoethane and its $\mathrm{Co}(\mathrm{II}), \mathrm{Ni}(\mathrm{II}), \mathrm{Cu}(\mathrm{II})$ and $\mathrm{Zn}(\mathrm{II}) \mathrm{com}$ plexes, Int J Electrochem Sci, 8 (2013), 8686-8699.

[20] M. B. Halli, R. B. Sumathi, and M. Kinni, Synthesis, spectroscopic characterization and biological evaluation studies of Schiff's base derived from naphthofuran-2-carbohydrazide with 8-formyl-7-hydroxy-4-methyl coumarin and its metal complexes, Spectrochim Acta A Mol Biomol Spectrosc, 99 (2012), 46-56.

[21] A. D. Garnovskii and I. S. Vasil' chenko, Rational design of metal coordination compounds with azomethine ligands, Russ Chem Rev, 71 (2002), 943-996.

[22] J. L. Dean, Lange's Handbook of Chemistry, McGraw-Hill, New York, 14th ed., 1992.

[23] A. A. Belal, M. A. Zayed, M. El-Desawy, and S. M. Rakha, Structure investigation of three hydrazones Schiff's bases by spectroscopic, thermal and molecular orbital calculations and their biological activities, Spectrochim Acta A Mol Biomol Spectrosc, 138 (2015), 49-57.

[24] S. Ilhan, H. Temel, I. Yilmaz, and M. Sekerci, Synthesis, structural characterization and electrochemical studies of new macrocyclic Schiff base containing pyridine head and its metal complexes, J Organomet Chem, 692 (2007), 3855-3865.

[25] E. M. Zayed, M. A. Zayed, and M. El-Desawy, Preparation and structure investigation of novel Schiff bases using spectroscopic, thermal analyses and molecular orbital calculations and studying their biological activities, Spectrochim Acta A Mol Biomol Spectrosc, 134 (2015), 155-164.

[26] F. A. Cotton, G. Wilkinson, C. A. Murillo, and M. Bochmann, Advanced Inorganic Chemistry, John Wiley \& Sons, New York, 6th ed., 1999.

[27] E. M. Zayed and M. A. Zayed, Synthesis of novel Schiff's bases of highly potential biological activities and their structure investigation, Spectrochim Acta A Mol Biomol Spectrosc, 143 (2015), 81-90.

[28] M. A. Zayed, M. A. Fahmey, M. El-Desawy, and Y. S. Farrag, Structure characterization of terazosin drug using mass spectrometry and thermal analyses techniques in comparison with semi-empirical molecular orbital (MO) calculations, J Therm Anal Calorim, 120 (2015), 1061-1069.

[29] M. Karthikeyan, D. Prasad, B. Poojary, K. Subrahmanya Bhat, B. Holla, and N. Kumari, Synthesis and biological activity of Schiff and Mannich bases bearing 2,4-dichloro-5-fluorophenyl moiety, Bioorg Med Chem, 14 (2006), 7482-7489.

[30] N. Shahabadi, Z. Ghasemian, and S. Hadidi, Binding studies of a new water-soluble iron(III) Schiff base complex to DNA using multispectroscopic methods, Bioinorg Chem Appl, 2012 (2012), 126451.

[31] S. Sen, N. A. Farooqui, S. Dutta, T. S. Easwari, V. Gangwar, K. Upadhya, et al., Physicochemical and biological evaluation of some Schiff base by conventional and microwave assisted method, Der Pharma Chemica, 5 (2013), 128-134.

[32] K. Singh, M. S. Barwa, and P. Tyagi, Synthesis, characterization and biological studies of $\mathrm{Co}(\mathrm{II}), \mathrm{Ni}(\mathrm{II}), \mathrm{Cu}(\mathrm{II})$ and $\mathrm{Zn}(\mathrm{II})$ complexes with bidentate Schiff bases derived by heterocyclic ketone, Eur J Med Chem, 41 (2006), 147-153.

[33] M. M. H. Khalil, E. H. Ismail, G. G. Mohamed, E. M. Zayed, and A. Badr, Synthesis and characterization of a novel Schiff base metal complexes and their application in determination of iron in different types of natural water, Open J Inorg Chem, 2 (2012), 18646.

[34] A. M. Hartman, M. Mondal, N. Radeva, G. Klebe, and A. K. H. Hirsch, Structure-based optimization of inhibitors of the aspartic protease endothiapepsin, Int J Mol Sci, 16 (2015), 19184-19194.

[35] M. B. Rao, A. M. Tanksale, M. S. Ghatge, and V. V. Deshpande, Molecular and biotechnological aspects of microbial proteases, Microbiol Mol Biol Rev, 62 (1998), 597-635.

[36] J. R. Naglik, S. J. Challacombe, and B. Hube, Candida albicans secreted aspartyl proteinases in virulence and pathogenesis, Microbiol Mol Biol Rev, 67 (2003), 400-428.

[37] P. K. Vuppala, D. R. Janagam, and P. Balabathula, Importance of $A D M E$ and bioanalysis in the drug discovery, J Bioequiv Availab, 5 (2013), e31.

[38] R. O. Potts and R. H. Guy, Predicting skin permeability, Pharm Res, 9 (1992), 663-669.

[39] J. B. Baell and G. A. Holloway, New substructure filters for removal of pan assay interference compounds (pains) from screening libraries and for their exclusion in bioassays, J Med Chem, 53 (2010), 2719-2740. 